\title{
Stimulation of the Immune System by Lactic Acid Bacteria
}

\author{
Takeshi TAKAHASHI* \\ Nutrition Science Institute, Meiji Milk Products Co., Ltd., 540 Naruda, Odawara 250-0862, Japan
}

Received for publication, September 26, 2000

\begin{abstract}
Probiotic bacteria are important functional foods capable of improving consumer health. Although most probiotic bacteria are derived from human intestinal flora, they are not indigenous to all individuals. It is very likely that probiotic bacteria are seen as exogenous or foreign antigens by the gut immune system. In research on orally administered lactic acid bacteria, it was found that serum antibody responses were induced not only against the whole bacterial cell, but also against cytoplasmic components. Mucosal immune responses were induced against cytoplasmic antigens and may be of relevance in the development of mucosal vaccines using lactic acid bacteria. These bacteria also exert an adjuvant effect on the mucosal IgA response against not only pathogenic organisms, but also dietary antigens. Furthermore, they enhance systemic immune responses such as phagocytic activity and serum antibody production. These biological responses have been shown in human studies and have formed the basis for oral bacteriotherapy with probiotic bacteria. Since the immunopotentiating activity of lactic acid bacteria is strain-dependent, it is important that special efforts be directed to selection criteria used for the identification of biologically active strains with probiotic function.
\end{abstract}

Key words: lactic acid bacteria; probiotics; gut-associated lymphoid tissues; mucosal IgA response; immunopotentiating activity

\section{INTRODUCTION}

When we ingest food, most dietary components such as protein, fat, and carbohydrate are digested and absorbed in the gut. Thus the gut was believed to be only one part of the alimentary tract. However, the recent enormous progress in the study of the mucosal immune system has highlighted the gut as the largest immune organ in the body (31). To prevent a host from invasion by microbe and dietary antigen, the gut has lymphoid tissues such as Peyer's patches, mesenteric lymph nodes, lamina propria, and intraepithelial lymphocytes, which are referred to as gut-associated lymphoid tissues (GALT). GALT play a key role in the production of intestinal IgA responses to pathogenic microorganisms and in the induction of systemic unresponsiveness (oral tolerance) to substantially innocuous food proteins, thereby contributing to adaptation for the host to the environmental antigens (4).

A growing interest in health and diet has recently produced the concept of functional foods, and many food products designed to provide health benefits have been developed (46). Probiotics are among them and are defined as live microbial food supplements that beneficially influence the host by improving its intestinal microbial balance. Their purported benefits are the

*Corresponding author. Mailing address: Nutrition Science Institute, Meiji Milk Products Co., Ltd., 540 Naruda, Odawara 250-0862, Japan. Phone: +81465-37-3661. Fax: +81-465-36-2776. E-mail: TAKESHI_TAKAHASHI @MEIJI-MILK.COM maintenance of normal intestinal and urogenital microflora, alleviation of lactose intolerance, reduction of serum cholesterol levels, anticarcinogenic activity, stimulation of the immune system, and improved nutritional value of food (47). Although fewer human studies have been done compared with other benefits, the efficacy of probiotics on stimulation of the immune system is thought to be very promising. This is because most probiotics contain lactic acid bacteria derived from the human gastrointestinal microflora that are closely associated with the development and stimulation of GALT. In fact, there is increasing experimental evidence to support the effect of orally administered lactic acid bacteria on the immune system. Furthermore, stimulation of the host immune system is suggested to be one possible mechanism providing protection against diarrhea and tumor by lactic acid bacteria. Table 1 shows selected examples of lactic acid bacteria, including studies on parenteral administration (37). The present review summarizes data concerning the stimulation of the immune system by lactic acid bacteria.

\section{IMMUNE RESPONSE TO ORALLY ADMINISTERED LACTIC ACID BACTERIA}

Although most probiotic strains are derived from human intestinal flora, they are not indigenous to all individuals, and their ability to colonize the intestine differs with each one. In fact, it was reported that exogenous bifidobacteria and lactobacilli could colonize the host transiently $(1,25)$. Furthermore, lamina propria 
Table 1. The effect of viable and nonviable probiotic bacteria on the immune system (37).

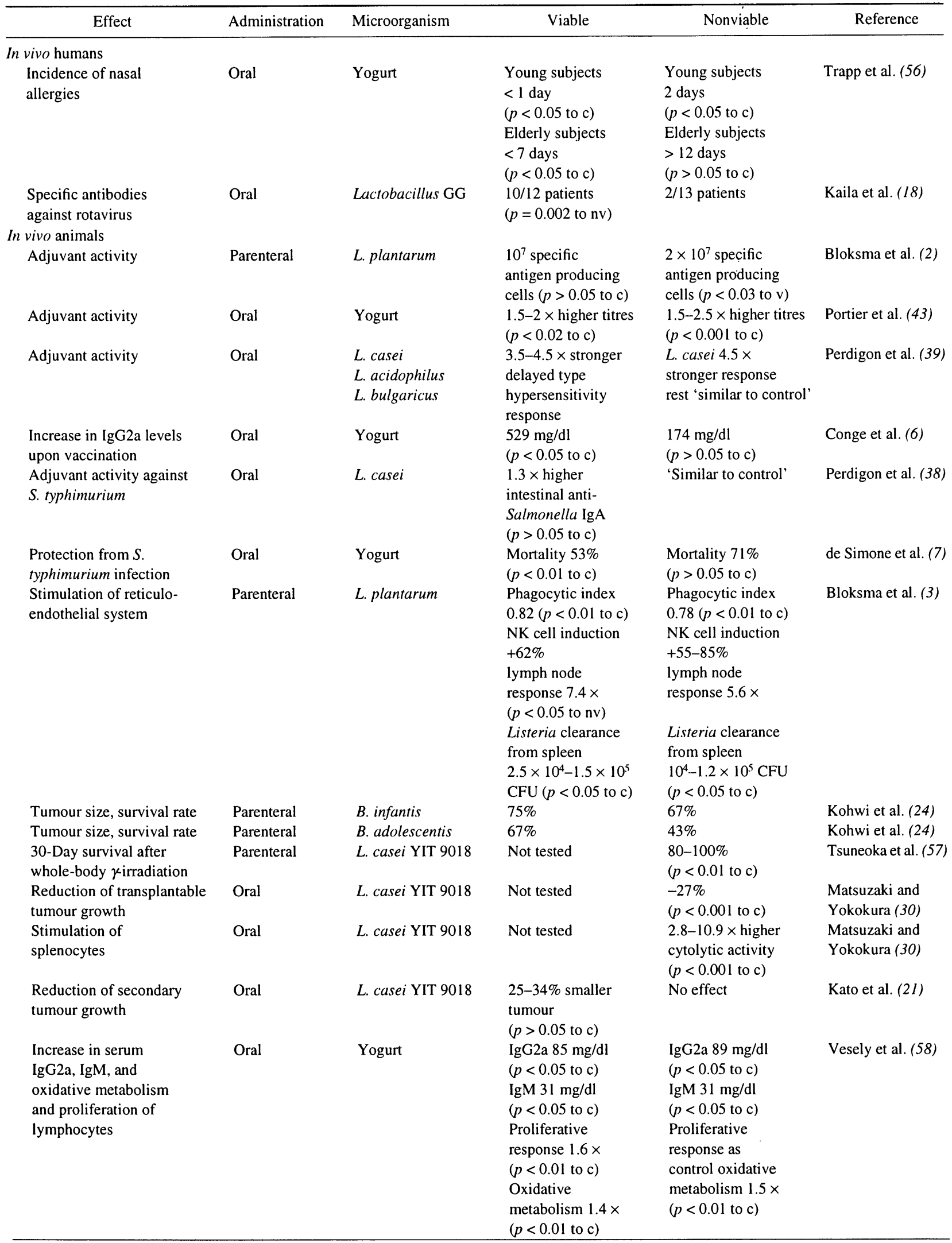


Table 1. (continued)

\begin{tabular}{|c|c|c|c|c|c|}
\hline Effect & Administration & Microorganism & Viable & Nonviable & Reference \\
\hline \multicolumn{6}{|l|}{ In vivo animals } \\
\hline Production of IFN $\alpha$ and $\beta$ & Parenteral & L. bulgaricus & $64 \mathrm{IU} / \mathrm{ml}$ & $\begin{array}{l}\text { Heated }<4 \mathrm{IU} / \mathrm{ml} \\
\text { irradiated } \\
350 \mathrm{IU} / \mathrm{ml}\end{array}$ & $\begin{array}{l}\text { Solis-Pereyra et al } \\
(50,5 I)\end{array}$ \\
\hline $\begin{array}{l}\text { Production of } \\
\text { interferon- } \gamma \text { by T-cells }\end{array}$ & Oral & Yogurt & $\begin{array}{l}20 \mathrm{U} / \mathrm{ml} \\
(p>0.05 \text { to } c)\end{array}$ & $1.7 \mathrm{U} / \mathrm{ml}$ & Halpern et al. (14) \\
\hline $\begin{array}{l}\text { Proliferative response } \\
\text { of Peyer's patch cells }\end{array}$ & Oral & Yogurt & $\begin{array}{l}50 \mathrm{cpm} / \mathrm{min} \\
(p<0.001 \text { to } \mathrm{c})\end{array}$ & $\begin{array}{l}40 \mathrm{cpm} / \mathrm{min} \\
(p<0.01 \text { to } \mathrm{c})\end{array}$ & de Simone et al. (8) \\
\hline $\begin{array}{l}\text { Immunoglobulin } \\
\text { expressing cells in } \\
\text { Peyer's patches }\end{array}$ & Oral & Yogurt & $\begin{array}{l}51 \% \text { after } 7 \text { and } 14 \\
\text { days }(p<0.01 \text { to } c)\end{array}$ & $\begin{array}{l}48 \% \text { after } 14 \text { days } \\
(p<0.05 \text { to } c)\end{array}$ & de Simone et al. (9) \\
\hline \multicolumn{6}{|l|}{ In vitro } \\
\hline $\begin{array}{l}\text { Induction of IFN } \alpha \text { in } \\
\text { murine macrophage cultures }\end{array}$ & & L. gasseri & Not tested & $\begin{array}{l}42.6 \mathrm{IU} / \mathrm{ml} \\
\text { (control } 9.7 \mathrm{IU} / \mathrm{ml} \text { ) }\end{array}$ & Kitazawa et al. (23) \\
\hline Induction of TNF- $\alpha$ and & & L. rhamnosus E509 & TNF- $\alpha$ & TNF- $\alpha$ & Miettinen et al. (32) \\
\hline $\begin{array}{l}\text { IL-6 in human peripheral } \\
\text { blood mononuclear }\end{array}$ & & L. rhamnosus GG & $\begin{array}{l}75-95 \mathrm{ng} / \mathrm{ml} \\
(p<0.001 \text { to nv })\end{array}$ & $\begin{array}{l}\text { Glutaraldehyde } \\
\text { fixed } 15 \mathrm{ng} / \mathrm{ml}\end{array}$ & \\
\hline blood leukocytes & & & IL-6 & IL-6 & \\
\hline & & & $\begin{array}{l}6 \mathrm{ng} / \mathrm{ml} \\
(p<0.01 \text { to } \mathrm{nv})\end{array}$ & $\begin{array}{l}\text { Glutaraldehyde } \\
\text { fixed } 2 \mathrm{ng} / \mathrm{ml}\end{array}$ & \\
\hline $\begin{array}{l}\text { INT-reductase activity of } \\
\text { human neutrophils and } \\
\text { guinea-pig macrophage }\end{array}$ & & E. faecium & $\begin{array}{l}+200 \%(p<0.001 \\
\text { to } c)\end{array}$ & $\begin{array}{l}\text { 'No differences in } \\
\text { effect of viable and } \\
\text { heat-inactivated' }\end{array}$ & Ebringer et al. (12) \\
\hline
\end{tabular}

$\mathrm{c}$, control (no bacteria); nv, nonviable; v, viable.

mononuclear cells were shown to be tolerant to bacteria residing in autologous but not heterologous human intestine (11). Therefore it is important to examine the immune response to orally administered lactic acid bacteria, even though probiotic bacteria are generally recognized as safe for human and animal consumption. Since lactic acid bacteria are candidates for antigen delivery vehicles for oral immunization (44), this information will also be useful for the development of the mucosal vaccine.

With regard to the immune response to lactic acid bacteria, serological studies for bacterial classification have been performed on many strains of lactobacilli, and these cellular fractions as teichoic acid and polysaccharide were found to be reactive to the antiserum from rabbits immunized parenterally with bacterial cells (20). However, only a few studies have been made on the immune response to lactic acid bacteria administered orally. Yasui et al. (60) reported immunogenicity of Bifidobacterium breve and change in antibody production in Peyer's patches after oral administration. Immunogenicity of $B$. breve was weak, and temporary serum antibody response to the organism was detected in mice fed these bacteria for more than 33 days. Antibody production against $B$. breve by Peyer's patch cells was also detected transiently in them. Furthermore, such weak immunogenicity of orally ingested lactic acid bacteria was shown in human study (5).
Because lactic acid bacteria have highly complex structures with many immunogenic epitopes, it is further important to determine which components of the whole bacteria cell are responsible for the serum antibody response to clarify the interaction of lactic acid bacteria with the immune system. The authors investigated the antibody response of mice to cell wall and cytoplasmic fractions of orally administered lactic acid bacteria (54). In mice fed with $B$. longum for more than 8 weeks, an antibody response to the cytoplasm of $B$. longum was detected, but not to the cell wall. On the other hand, in mice fed with Lactobacillus acidophilus for more than 6 weeks, an antibody response to the cytoplasm and to the cell wall of L. acidophilus was detected. Moreover, feeding each organism for 2 weeks enhanced the proliferative response of Peyer's patch cells to the cell fraction against which the serum antibody was detected. This suggests that the immune response to lactic acid bacteria differs with the bacterial strains tested and that cytoplasmic fractions of lactic acid bacteria are associated with the interaction between dietary lactic acid bacteria and the host immune system. It is interesting that a Western blot analysis of proteins derived from the cytoplasmic fractions of $B$. longum and reacted with sera from mice orally immunized with $B$. longum defined several proteins that are not recognized by mice parenterally immunized with B. longum (Fig. 1). Similarly, Norton et al. (36) de- 


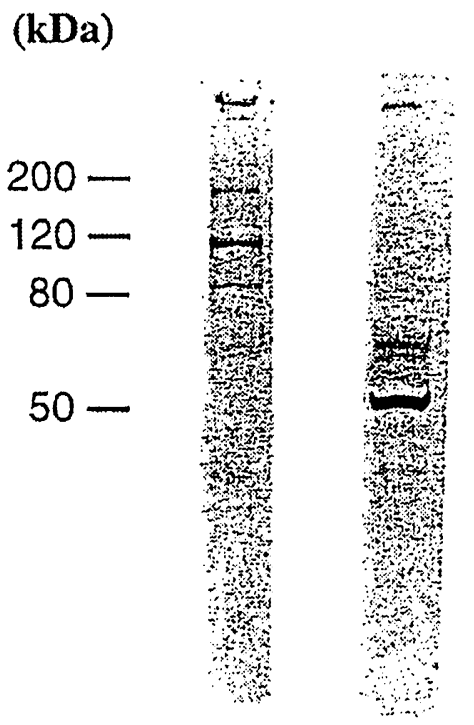

Fig. 1. Western blot showing the reactivity of sera from mice fed for 12 weeks with or immunized parenterally with $B$. longum to the cytoplasmic fractions of $B$. longum cell. Lane 1: sera from mice fed for 12 weeks with $B$. longum; Lane 2: sera from mice immunized parenterally with $B$. longum. Size markers are indicated.

tected serum antibody responses to subcellular protein fractions derived from $L$. lactis following oral inoculation of $L$. lactis by a Western blot analysis. The examination of these proteins may give clues to the development of mucosal vaccine.

\section{EFFECT OF ORALLY ADMINISTERED LACTIC ACID BACTERIA ON THE IMMUNE RESPONSE TO ENVIRONMENTAL ANTIGENS}

The production and expression of secretory $\operatorname{IgA}$, the most abundant immunoglobulin in mucosal secretions, is central to the gut immune function (31). Thus to protect the host against an invasion of pathogenic organisms, antigens, and toxic substances from the gut lumen, the enhancement of specific and nonspecific IgA response appears to be necessary for the efficacy of probiotics. In this regard, several investigations suggest that orally administered lactic acid bacteria increase the mucosal IgA response to foreign substances.

For example, Perdigon et al. (40) found that intestinal IgA antienteropathogen levels were higher in mice previously fed for 2 days with $L$. casei than in control mice after Salmonella typhimurium or enterotoxigenic Escherichia coli challenge. Yasui et al. (59) showed that the level of antirotavirus IgA in the milk of mouse dams fed $B$. breve was significantly higher than in the milk of control dams after rotavirus challenge. Furthermore, Tejada-Simon et al. (55) indicated that the fecal IgA anticholera toxin level was much higher in mice fed yogurt with bifidobacteria and $L$. acidophilus than in mice fed skim milk. Since these pathogenic organisms and toxin are associated with a high rate of infant mortality and morbidity, especially in developing countries, dietary lactic acid bacteria are expected to contribute to the host defense also in humans. In fact, infants fed fermented milk containing Lactobacillus GG showed an increase in the specific IgA response to rotavirus and earlier recovery from rotavirus diarrhea, compared with the control group (19).

On the other hand, more and more infants are suffering from food allergies in developed countries. It is currently recognized that some dietary protein antigens may remain partly intact in the gastrointestinal tract and cause most of the allergic reactions (4). This suggests that mucosal defense against dietary protein antigens may be important for the prevention of allergic reactions to them. However, few reports have been made on the effects of lactic acid bacteria on the host defense against luminal dietary antigens. Thus the authors investigated the effects of lactic acid bacteria on the mucosal IgA response of mice to $\beta$-lactoglobulin ( $\beta$-LG), a whey protein antigen often ingested with lactic acid bacteria in dairy foods such as yogurt (53). The anti- $\beta$ LG IgA level in tissue extracts of the small intestinal wall was much higher in mice fed the $B$. longum diet for 2 weeks than in control mice. Furthermore, the in vitro IgA response of Peyer's patch (PP) cells to $\beta$-LG was detected only when PP cells from mice fed $B$. longum were assayed, not when those from control mice were assayed. These results suggest that orally ingested lactic acid bacteria have an adjuvant effect on the mucosal IgA response to dietary protein antigens as well as to pathogenic organisms. Our findings compare favorably with the observations of Fukushima et al. (13), who have shown that the level of anti- $\beta$-LG IgA in fecal extracts was significantly higher in mice fed bifidobacteria than the level in control mice.

Recently, Sudo et al. (52) reported the role of intestinal bacterial flora in oral tolerance to the IgE response. The reconstitution of intestinal flora of germfree mice with $B$. infantis restored the susceptibility of the IgE response to oral tolerance induction only when the bacteria were inoculated into these mice at the neonatal stage, but not at an older age. Thus they suggested that exposure to intestinal microflora at the neonatal stage is required if GALT is to become fully developed and generate competent regulatory cells. In accordance with 
this, Sepp et al. (49) have shown that the prevalence of atopic disease is low in Estonia and high in Sweden and that the differences in intestinal microflora include more lactobacilli in the former.

Taken together, probiotic bacteria have been suggested to promote endogenous barrier mechanisms in a host. This notion is supported by the observations of Majamaa and Isolauri (27), who applied probiotic bacteria to the treatment of food allergy and alleviated the intestinal inflammation in patients.

Furthermore, it is well known that orally administered lactic acid bacteria increase the systemic immune response in a host (41). Especially, there are accumulating data to support their enhancing effect on phagocytic activity and antibody production also in man $(10$, 17, 48). These studies seem to form the basis for oral bacteriotherapy with probiotic bacteria.

\section{STRAIN DEPENDENCY OF THE IMMUNOPOTENTI- ATING ACTIVITY OF LACTIC ACID BACTERIA}

Since most lactic acid bacteria such as lactobacilli and bifidobacteria are normal intestinal microflora of humans and generally recognized as safe, little attention was paid previously to the difference of probiotic effect among species or strains. However, several different in vitro assays have been developed to screen new strains of bacteria for their ability to act as probiotics and to provide a health benefit to the host (45). This is so also for the selection of strains with high immunopotentiating activity.

Yasui et al. (61) screened 120 strains of bifidobacteria isolated from human feces by using the PP cell culture method and found three strains of bifidobacteria inducing large quantities of IgA among them. Lee et al. (26) investigated the mitogenic activity of bifidobacteria and lactobacilli using spleen, thymus, and PP cells and indicated that the occurrence of immunopotentiating activity was dependent on the properties of individual strains instead of on the species or microbial culture conditions. Furthermore, Marin et al. $(28,29)$ evaluated the effect of streptococci, lactobacilli, and bifidobacteria on cytokine production by using a clonal macrophage and T-cell lines and selected several strains that stimulated cytokine production strongly. Therefore a knowledge of the identity of probiotic strains used seems to be a prerequisite for the development of probiotic bacteria that most effectively enhance the immune response.

In the dairy industry, Lactobacillus delbrueckii subsp. bulgaricus is historically one of the most widely used and best characterized bacteria strains. However, little information is available on the strain dependence of the immunopotentiating activity for $L$. delbrueckii subsp. bulgaricus. Thus the authors screened 90 strains of this bacterial species for the proliferative response of spleen and $\beta$-LG-primed lymph node cells (34). The immunopotentiating activity varied greatly between strains. Among them, several, including 1023, showed strong activity. Furthermore, strain 1023 had the strongest mitogenic activity for PP cells and induced IgA antibody production by PP cells as strongly as the $B$. longum strain that previously had been shown to have an oral adjuvant effect. These results suggest that $L$. delbrueckii subsp. bulgaricus strains such as 1023 may be useful for the production of fermented milk with a more beneficial effect on the host immune system.

What components are responsible for the strain dependence of the immunopotentiating activity of lactic acid bacteria? Although it is generally recognized that the immunomodulatory factor derived from Gram-positive bacteria is peptidoglycan contained in the cell wall (15), there have been controversial results on the immunoactive fractions of lactic acid bacteria. Indeed, Namioka et al. (35) demonstrated that the number of IgA-bearing cells in the lamina propria of the small intestine was significantly larger in the piglets fed with peptidoglycan from bifidobacteria than the control piglets. However, Morata de Ambrosini et al. (33) observed that the oral administration of peptidoglycan from $L$. casei did not produce an IgA increase in mouse intestinal fluid, whereas the whole bacterial cell did. Furthermore, Hatcher and Lambrecht (16) showed that cellfree extracts from L. acidophilus and B. longum enhanced macrophage activity, which is consistent with our findings that the oral administration of these organisms induced a proliferative response of PP cells to their cytoplasm (54). Also with $L$. delbrueckii subsp. bulgaricus 1023, a mitogenic response of spleen and PP cells was detected to both the cell wall and the cytoplasm of the strain (Table 2). Therefore additional components not included in the cell wall fraction are hypothesized to be involved in immunostimulation by lactic acid bacteria.

Besides bacterial products such as peptidoglycan and polysaccharide, recent studies indicate that bacterial DNA stimulates B cells, T cells, and macrophages to proliferate, secrete antibodies, and/or produce cytokines (42). This immunopotentiating DNA is reported to contain six base pair motifs consisting of an unmethylated CpG dinucleotide flanked by two 5'-purines and two 3'-pyrimidines. In contrast with this, a novel DNA motif inducing mitogenic activity has been found in DNAs 
Table 2. Mitogenic response of spleen and PP cells to the cell fractions of $L$. delbrueckii subsp. bulgaricus 1023a.

\begin{tabular}{|c|c|c|}
\hline Sample & Spleen & PP \\
\hline None (control) & $1.1 \pm 0.1$ & $1.1 \pm 0.3$ \\
\hline Cell wall & $6.0 \pm 0.5$ & $13.4 \pm 2.0$ \\
\hline Cytoplasm & $7.2 \pm 0.5$ & $7.7 \pm 0.6$ \\
\hline \multicolumn{3}{|c|}{$\begin{array}{l}\text { a Spleen and PP cells were cultured with the cell fractions } \\
\text { of } L \text {. delbrueckii subsp. bulgaricus } 1023(100 \mu \mathrm{g} / \mathrm{ml}) \text { for } \\
\text { three days, and }\left[{ }^{3} \mathrm{H}\right] \text { thymidine uptake was then assessed } \\
\text { by } 20 \mathrm{hr} \text { pulsing and is expressed as the mean of the stimu- } \\
\text { lation index. Error bars indicate standard deviations for } \\
\text { three wells. }\end{array}$} \\
\hline
\end{tabular}

from lactic acid bacteria (22). Thus it seems tempting to speculate that such oligodeoxynucleotides might be a candidate substance for immunoactive components in cell-free extracts of lactic acid bacteria. Further study will be needed to determine which cell components of lactic acid bacteria are responsible for the strain dependence of the immunopotentiating activity.

Acknowledgements. The author would like to thank Dr. S. Nagafuchi for his contributions with the study on screening $L$. delbrueckii subsp. bulgaricus strains and Toshi Nara-Oka and Emiko Nakagawa for their excellent technical assistance. The author is also grateful to Drs. H. Iwana, T. Kaneko, T. Sasaki, T. Yajima, Y. Yamamoto, and T. Kuwata for their helpful discussions and to Drs. K. Hirayama and K. Itoh (The University of Tokyo) for providing human-flora-associated mice and their helpful discussions. The author would also like to thank Dr. J. C. Chin (Elizabeth Macarthur Agricultural Institute) for the critical reading of the manuscript.

\section{REFERENCES}

(1) Bennet R, Nord CE, Zetterstrom R. 1992. Transient colonization of the gut of newborn infants by orally administered bifidobacteria and lactobacilli. Acta Paediatr 81: 784 788.

(2) Bloksma N, de Heer E, van Dijk H, Willers JM. 1979. Adjuvanticity of lactobacilli. I. Differential effects of viable and killed bacteria. Clin Exp Immunol 37: 367-375.

(3) Bloksma N, Ettekoven H, Hofhuis FM, van Noorle-Jansen L, de Reuver MJ, Kreeftenberg JG, Willers JM. 1981. Effects of lactobacilli on parameters of nonspecific resistance of mice. Med Microbiol Immunol 170: 45-53.

(4) Brandtzaeg P. 1998. Development and basic mechanisms of human gut immunity. Nutr Rev 56: S5-S18.

(5) Carlsson P, Bratthall D. 1985. Secretory and serum antibodies against Streptococcus lactis, Streptococcus thermophilus, and Lactobacillus bulgaricus in relation to ingestion of fermented milk products. Acta Odontol Scand 43:
147-153.

(6) Conge G-A, Gouache P, Desormeau-Bedot JP, Loisillier F, Lemonnier D. 1980. Effects compares dun regime enrichi en yoghourt vivant ou thermise sur le systeme immunitaire de la souris. Reprod Nutr Dev 20: 929-938.

(7) de Simone C, Tzanttzoglou S, Baldinelli L, di Fabio S, Bianchi Salvadori B, Jirillo E, Vesely R. 1988. Enhancement of host resistance against Salmonella typhimurium infection by a diet supplemented with yoghurt. Immunopharmacol Immunotoxicol 10: 399-415.

(8) de Simone C, Vesely R, Bianchi Salvadori B, Jirillo E. 1993. The role of probiotics in modulation of the immune system in man and animals. Int J Immunother IX: 23-28.

(9) de Simone C, Vesely R, Negri R, Bianchi Salvadori B, Zanzoglu S, Cilli A, Lucci L. 1987. Enhancement of immune response of murine Peyer's patches by a diet supplemented with yoghurt. Immunopharmacol Immunotoxicol 9: $87-100$.

(10) Donnet-Hughes A, Rochat F, Serrant P, Aeschlimann JM, Schiffrin EJ. 1999. Modulation of nonspecific mechanisms of defense by lactic acid bacteria: effective dose. J Dairy Sci 82: 863-869.

(11) Duchmann R, Kaiser I, Hermann E, Mayet W, Ewe K, Meyer zum Buschenfelde K-H. 1995. Tolerance exists towards resident intestinal flora but is broken in active inflammatory bowel disease (IBD). Clin Exp Immunol 102: 448-455.

(12) Ebringer L, Ferencik M, Lahitova N, Kacani L, Michalkova D. 1995. Anti-mutagenic and immunostimulatory properties of lactic acid bacteria. World J Microbiol Immunol 11: 294-298.

(13) Fukushima Y, Kawata Y, Mizumachi K, Kurisaki J, Mitsuoka T. 1999. Effect of bifidobacteria feeding on fecal flora and production of immunoglobulins in lactating mouse. Int J Food Microbiol 46: 193-197.

(14) Halpern GM, Vruwink KG, van de Water J, Keen CL, Gershwin ME. 1991. Influence of long-term yoghurt consumption in young adults. Int J Immunother VII: 205-210.

(15) Hamann L, EL-Samalouti V, Ulmer AJ, Flad H-D, Rietschel ET. 1998. Components of gut bacteria as immunomodulators. Int J Food Microbiol 41: 141-154.

(16) Hatcher GE, Lambrecht RS. 1993. Augmentation of macrophage phagocytic activity by cell-free extracts of selected lactic acid-producing bacteria. J Dairy Sci 76: 2485-2492.

(17) Ivanova T, Jekova M. 1997. Preventive role of lyophilic dairy products bulgaricum and biostim. Cancer Lett 114: 93-95.

(18) Kaila M, Isolauri E, Saxelin M, Arvilommi H, Vesikari T. 1995. Viable versus inactivated lactobacillus strain GG in acute rotavirus diarrhoea. Arch Dis Child 72: 51-53.

(19) Kaila M, Isolauri E, Soppi E, Virtanen E, Laine S, Arvilommi H. 1992. Enhancement of the circulating antibody secreting cell response in human diarrhea by a human Lactobacillus strain. Pediatr Res 32: 141-144.

(20) Kandler O, Weiss N. 1986. Regular, nonsporing Gram-positive rods. In Bergey's Manual of Systematic Bacteriology, Sneath PHA (ed), Williams \& Wilkins, Baltimore, p. 12081260. 
(21) Kato I, Endo K, Yokokura T. 1994. Effects of oral administration of Lactobacillus casei on antitumor responses induced by tumor resection in mice. Int J Immunopharmacol 16: $29-36$.

(22) Kitazawa H, Itoh S, Konno K, Yamaguchi T, Saito T, Itoh T. 1998. DNA motif(s) from Lactobacillus gasseri induce lymphocyte activation. J Dairy Sci 81 (Suppl 1): 33.

(23) Kitazawa H, Tomioka Y, Matsumura K, Aso H, Mizugaki M, Itoh T, Yamaguchi T. 1994. Expression of mRNA encoding IFN $\alpha$ in macrophages stimulated with Lactobacillus gasseri. FEMS Microbiol Lett 120: 315-322.

(24) Kohwi Y, Imai K, Tamura Z, Hashimoto Y. 1978. Antitumor effect of Bifidobacterium infantis in mice. Gann 69: 613-618.

(25) Kullen MJ, Amann MM, O'Shaughnessy MJ, O'Sullivan DJ, Busta FF, Brady LJ. 1997. Differentiation of ingested and endogenous Bifidobacteria by DNA fingerprinting demonstrates the survival of an unmodified strain in the gastrointestinal tract of humans. J Nutr 127: 89-94.

(26) Lee J, Ametani A, Enomoto A, Sato Y, Motoshima H, Ike F, Kaminogawa S. 1993. Screening for the immunopotentiating activity of food microorganisms and enhancement of the immune response by Bifidobacterium adolescentis M101-4. Biosci Biotechnol Biochem 57: 2127-2132.

(27) Majamaa H, Isolauri E. 1997. Probiotics: A novel approach in the management of food allergy. J Allergy Clin Immunol 99: 179-185.

(28) Marin ML, Lee JH, Murtha J, Ustunol Z, Pestka JJ. 1997. Differential cytokine production in clonal macrophage and T-cell lines cultured with bifidobacteria. J Dairy Sci 80: 2713-2720.

(29) Marin ML, Tejada-Simon MV, Lee JH, Murtha J, Ustunol Z, Pestka JJ. 1998. Stimulation of cytokine production in clonal macrophage and T-cell models by Streptococcus thermophilus: comparison with Bifidobacterium sp. and Lactobacillus bulgaricus. J Food Prot 61: 859-864.

(30) Matsuzaki T, Yokokura T. 1989. Antitumor effect of oral administration of Lactobacillus casei in newborn mice. Igaku no Ayumi 150: 745-746.

(31) McGhee JR, Kiyono H. 1999. The mucosal immune system. In Fundamental Immunology, 4th ed, Paul WE (ed), Lippincott-Raven Publishers, Philadelphia, p. 909-945.

(32) Miettinen M, Vuopio-Varkila J, Varkila K. 1996. Production of human tumor necrosis factor alpha, interleukin-6, and interleukin-10 is induced by lactic acid bacteria. Infect Immun 64: 5403-5405.

(33) Morata de Ambrosini V, Gonzalez S, Perdigon G, Pesce de Ruiz Holgado A, Oliver G. 1998. Immunostimulating activity of cell walls from lactic acid bacteria and related species. Food Agric Immunol 10: 183-191.

(34) Nagafuchi S, Takahashi T, Yajima T, Kuwata T, Hirayama K, Itoh K. 1999. Strain dependency of the immunopotentiating activity of Lactobacillus delbrueckii subsp. bulgaricus. Biosci Biotechnol Biochem 63: 474-479.

(35) Namioka S, Sasaki T, Maede Y. 1991. Immunopotentiation of the small intestine of weaning piglets by peptidoglycan derived from Bifidobacterium thermophilum. Bifidobacteria Microflora 10: 1-9.
(36) Norton PM, Brown HWG, Le Page RWF. 1995. Mucosal and systemic responses following enteric exposure to lactic acid bacteria. In Advances in Mucosal Immunology, Mestecky J, et al. (eds), Plenum Press, New York, p. 1559 1562.

(37) Ouwehand AC, Salminen SJ. 1998. The health effects of cultured milk products with viable and non-viable bacteria. Int Dairy J 8: 749-758.

(38) Perdigon G, Alvarez S, Gobbato N, de Budeguer MV, de Ruiz Holgado AAP. 1995. Comparative effect of the adjuvant capacity of Lactobacillus casei and lipopolysaccharide on the intestinal secretory antibody response and resistance to Salmonella infection in mice. Food Agric Immunol 7: 283-294.

(39) Perdigon G, Alvarez S, Nader de Macias ME, Pesce de Ruiz Holgado AA. 1988. Actividad adyuvante de bacterias lacticas: perspectivas para su uso en vacunas orales. Rev Argent Microbiol 20: 141-146.

(40) Perdigon G, Alvarez S, Pesce de Ruiz Holgado A. 1991. Immunoadjuvant activity of oral Lactobacillus casei: influence of dose on the secretory immune response and protective capacity in intestinal infections. J Dairy Res 58: 485-496.

(41) Perdigon G, Alvarez S, Rachid M, Aguero G, Gobbato N. 1995. Symposium: probiotic bacteria for humans: clinical systems for evaluation of effectiveness. J Dairy Sci 78: 1597-1606.

(42) Pisetsky DS. 1996. Immune activation by bacterial DNA: a new genetic code. Immunity 5: 303-310.

(43) Portier A, Boyaka NP, Bougoudogo F, Dubarry M, Huneau JF, Tome D, Dodin A, Cost M. 1993. Fermented milks and increased antibody responses against cholera in mice. Int $\mathbf{J}$ Immunother IX: 217-224.

(44) Pouwels PH, Leer RJ, Shaw M, Heijne den Bak-Glashouwer M-J, Tielen FD, Smit E, Martinez B, Jore J, Conway PL. 1998. Lactic acid bacteria as antigen delivery vehicles for oral immunization purposes. Int J Food Microbiol 41: 155167.

(45) Prasad J, Gill H, Smart J, Gopal PK. 1998. Selection and characterisation of Lactobacillus and Bifidobacterium strains for use as probiotics. Int Dairy J 8: 993-1002.

(46) Salminen S, Bouley C, Boutron-Ruault M-C, Cummings JH, Franck A, Gibson GR, Isolauri E, Moreau M-C, Roberfroid M, Rowland I. 1998. Functional food science and gastrointestinal physiology and function. Br J Nutr 80 (Suppl 1): S147-S171.

(47) Sanders ME. 1993. Effect of consumption of lactic cultures on human health. In Advances in Food and Nutrition Research, Kinsella JE (ed), Academic Press, London, p. 67-130.

(48) Schiffrin EJ, Brassart D, Servin AL, Rochat F, DonnetHughes A. 1997. Immune modulation of blood leukocytes in humans by lactic acid bacteria: criteria for strain selection. Am J Clin Nutr 66: 515S-520S.

(49) Sepp E, Julge K, Vasar M, Naaber P, Bjorksten B, Mikelsaar M. 1997. Intestinal microflora of Estonian and Swedish infants. Acta Paediatr 86: 956-961.

(50) Solis-Pereyra B, Aattouri N, Lemonnier D. 1997. Role of 
food in the stimulation of cytokine production. Am J Nutr 66: 521S-525S.

(51) Solis-Pereyra B, Falcoff R, Falcoff E, Lemonnier D. 1991. Interferon induction by Lactobacillus bulgaricus and Streptococcus thermophilus in mice. Eur Cytokine Netw 2: 299303.

(52) Sudo N, Sawamura S, Tanaka K, Aiba Y, Kubo C, Koga Y. 1997. The requirement of intestinal bacterial flora for the development of an IgE production system fully susceptible to oral tolerance induction. J Immunol 159: 1739-1745.

(53) Takahashi T, Nakagawa E, Nara T, Yajima T, Kuwata T. 1998. Effects of orally ingested Bifidobacterium longum on the mucosal IgA response of mice to dietary antigens. Biosci Biotechnol Biochem 62: 10-15.

(54) Takahashi T, Oka T, Iwana H, Kuwata T, Yamamoto Y. 1993. Immune response of mice to orally administered lactic acid bacteria. Biosci Biotechnol Biochem 57: 15571560.

(55) Tejada-Simon MV, Lee JH, Ustunol Z, Pestka JJ. 1999. Ingestion of yogurt containing Lactobacillus acidophilus and Bifidobacterium to potentiate immunoglobulin A responses to cholera toxin in mice. J Dairy Sci 82: 649-660.
(56) Trapp C, Chang CC, Halpern GM, Keen CL, Gershwin ME. 1993. The influence of long term yoghurt consumption in young adults. Int J Immunother IX: 53-64.

(57) Tsuneoka K, Ishihara H, Dimchev AB, Yokokura T, Shikita M. 1994. Timing in administration of a heat-killed Lactobacillus case $i$ preparation for radioprotection in mice. $\mathbf{J}$ Radiation Res 35: 147-156.

(58) Vesely R, Negri R, Bianchi Salvadori B, Lavezzari D, de Simone C. 1985. Influence of a diet additioned with yogurt on the mouse immune system. J Immunol Immunopharmacol 51: 30-35.

(59) Yasui H, Kiyoshima J, Ushijima H. 1995. Passive protection against rotavirus induced diarrhea of mouse pups born to and nursed by dams fed Bifidobacterium breve YIT4064. J Infect Dis 172: 403-409.

(60) Yasui H, Mike A, Ohwaki M. 1989. Immunogenicity of Bifidobacterium breve and change in antibody production in Peyer's patches after oral administration. J Dairy Sci 72: 30-35.

(61) Yasui H, Nagaoka N, Mike A, Hayakawa K, Ohwaki M. 1992. Detection of Bifidobacterium strains that induce large quantities of IgA. Microbial Ecol Health Dis 5: 155-162. 